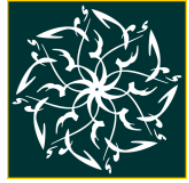

JAS: Jurnal Ilmiah Ahwal Syakhshiyyah

Volume 1 Nomor 1 Tahun 2019

e-ISSN:

\title{
STUDI KOMPARASI KONSEP KEWARISAN ANAK TIRI PERSPEKTIF KOMPILASI HUKUM ISLAM (KHI)
}

\author{
Ibnu Jazari \\ FAI Unisma Malang \\ e-mail: ibnujazari11@gmail.com,
}

Diterima: 13 - 05 - 2019 | Direvisi: 01 - 06 - 2019 | Disetujui: 10 - 06 - 2019

(C) 2019 Program Studi Ahwal Syakhshiyyah Fakultas Agama Islam Universitas Islam Malang

\begin{abstract}
Abstrak
Masalah yang masih diperselisihkan atau masih menjadi persoalan pendapat dikalangan ulama', misalnya tentang bagian dari kewarisan anak Tiri. Dalam kewarisan Islam, masyarakat Indonesia yang mayoritas penganut madzab Imam Syafi'i dan juga aturan dari KHI (Kompilasi Hukum Islam) yang menjadi aturan bagi masyarakat Indonesia, dibuat bingung. Pemikiran imam Syafi'i dan KHI (Kompilasi Hukum Islam) yang notabene masyarakat Indonesia sebagai penganut madzab Imam Syafi'i, Dalam kewarisan anak tiri ini berbeda dengan aturan dalam KHI (Kompilasi Hukum Islam) yang juga dibuat dengan melihat keadaan sosio budaya dan madzab yang dianut oleh masyarakatnya. Metode penelitian dengan library research atau penelitian pustaka. Anak tiri dalam hukum waris Islam tidak secara langsung tergolong sebagai ahli waris karena tidak terdapat sebab mewarisi (asbabul miirats). Tetapi dengan menggunakan alternatif lain dalam hukum waris Islam, anak tiri tidak akan kehilangan haknya untuk mendapatkan perlindungan dari orang tuanya, sebagai anak bawaan dari ayah dan ibu kandung-nya. Dan dalam hukum waris Islam, anak tiri bisa mendapatkan harta warisan dari perkawinan ayah atau ibu kandungnya yang baru (keluarganya yang baru) dengan cara Qiyas dan Wasiat Wajibah sebesar $1 / 3$.
\end{abstract}

Kata kunci: komparasi, kewarisan, anak tiri, prespektif, kompilasi hukum Islam

This work is licensed under Creative Commons Attribution Non Commercial 4.0 International License Available online on: http://riset.unisma.ac.id/index.php/fai/index 
Studi Komparasi Konsep Kewarisan Anak Tiri

Perspektif Kompilasi Hukum Islam (KHI)

\section{A. PENDAHULUAN}

Al-Qur'an diturunkan kepada umat manusia melalui Nabi Muhammad SAW 16 abad yang lalu sebagai petunjuk dan pedoman hidup bagi manusia, maka secara universal segala aspek kehidupan manusia telah diatur dalam Al-Qur'an. Demikian juga mengenai hukum kewarisan, Al-Qur'an juga telah mengaturnya.

Hukum kewarisan merupakan bagian dari hukum kekeluargaan yang memegang peranan sangat penting. Hal ini disebabkan dalam hukum kewarisan ini sangat erat dengan ruang lingkup kehidupan manusia. Karena pada dasarnya setiap manusia akan mati/meninggal dunia. Apabila suatu peristiwa meninggalnya seseorang maka sekaligus akan menimbulkan akibat hukum yaitu tentang bagaimana pengurusan dan kelanjutan hak-hak dan kewajiban sebagai akibat dari adanya peristiwa hukum karena meninggalnya seseorang telah diatur dalam hukum kewarisan (Ramulyo, 1984:2). Hal ini menjadikan pentingnya hukum kewarisan untuk dipelajari sebagaimana sabda Rasulullah SAW yang diriwayatkan oleh AtTirmidzi dan Daruqutni yang artinya:

"Pelajarilah Al-Qur'an dan ajarkanlah kepada orang-orang dan pelajarilah ilmu faraid serta ajarkanlah kepada orang-orang. Karena saya adalah orang yang bakal direnggut (mati), sedang ilmu itu bakal diangkat. Hampir-hampir saja dua orang yang bertengkar tentang pembagian pusaka, maka mereka berdua tidak menemukan seorangpun yang sanggup memfatwakannya kepada mereka”. (Ad-Daruquthniy, 1994:40)

Di Negara kita Republik Indonesia ini, hukum waris yang berlaku secara nasional belum terbentuk hingga kini ada tiga macam hukum waris yang berlaku dan diterima oleh masyarakat Indonesia, yakni hukum waris yang berdasar hukum Islam, hukum adat dan hukum perdata Eropa (BW). (Zuhdi,1997:195)

Masalah yang menyangkut warisan seperti halnya masalah yang dihadapi manusia, ada yang sudah di jelaskan permasalahannya dalam Al-Qur'an/Sunnah dengan keterangan yang kongkrit, sehingga tidak timbul macam-macam intrepretasi, bahkan tercapai ijma' (konsensus) dikalangan ulama dan umat Islam (Zuhdi, 1997:196). Akan tetapi ada juga masalah yang masih diperselisihkan atau masih menjadi persoalan pendapat dikalangan ulama', misalnya tentang bagian dari kewarisan anak Tiri. Dalam kewarisan Islam, masyarakat Indonesia yang mayoritas penganut madzab Imam Syafi'i dan juga aturan dari KHI (Kompilasi Hukum Islam) yang menjadi aturan bagi masyarakat Indonesia, dibuat bingung. Pemikiran imam

JAS: Volume 1 Nomor 1, 2019 
Syafi'i dan KHI (Kompilasi Hukum Islam) yang notabene masyarakat Indonesia sebagai penganut madzab Imam Syafi'i, Dalam kewarisan anak tiri ini berbeda dengan aturan dalam KHI (Kompilasi Hukum Islam) yang juga dibuat dengan melihat keadaan sosio budaya dan madzab yang dianut oleh masyarakatnya.

Dalam KHI (Kompilasi Hukum Islam) dijelaskan bahwa seorang anak tiri tetap mendapat bagian dari harta peninggalan orang tua angkatnya. Sebagaimana diatur dalam pasal 209 KHI (Kompilasi Hukum Islam) Berdasar keterangan diatas maka untuk mengetahui seberapa jauh efektifitas aturan kedua hukum tersebut mengatur dan memberi pedoman terhadap kewarisan anak tiri diperlukan kajian yang bersifat komperatif.

Berikut ini beberapa contoh masalah pewarisan yang terjadi saat ini. Yang pertama. Sengketa Warisan antar Anak dari Ibu yang Berbeda. Teman saya perempuan, beragama Islam. Sekitar tujuh tahun lalu bapak dan ibunya bercerai. Lima tahun lalu, bapaknya meninggal dunia. Lalu dua tahun kemudian ibunya meninggal dunia. Terdapat sebuah rumah atas nama bapaknya. Akan tetapi, muncul orang-orang yang mengaku anak-anak bapaknya dari sekitar tiga orang istri lainnya (selain ibunya). Mereka mengaku dan mereka bisa membuktikan kebenaran kalau mereka anak kandung bapaknya, tetapi memang tiga istri itu sudah dicerai jauh sebelum ibu dan bapak temen saya ini menikah (jadi mungkin ibunya itu pernikahan keempat).

Yang menjadi masalah adalah anak-anak dari istri yang sudah dicerai itu, bagaimana pembagian haknya dengan temen saya dan kakaknya. Rumah tersebut sekarang mau dijual, tetapi yang jadi masalah, ahli waris yang harusnya mewakili. Yang menjadi pertanyaan yaitu siapakah ahli waris yang berhak dan bagaimana caranya? Yang kedua. Cara membagi warisan anak kandung dan anak tiri, Janda A mempunyai 3 anak kawin dengan perjaka B, setelah nikah A dan B mempunyai anak 2 laki-laki. Jumlah anak hasil perkawinan $A+B=5$ anak, saat ini A dan Btelah wafat semua.

Berdasarkan uraian tersebut diatas, penulis tertarik untuk mengkaji dari segi hukum mengenai kedudukan hak waris anak tiri yang lahir dalam perkawinan sah dan bagaimana pembagian hak waris terhadap anak tiri menurut hukum waris Islam, melalui sebuah karya tulis dalam bentuk skripsi dengan judul: "Kedudukan Hak Waris Anak Tiri dalam Perkawinan Sah menurut Hukum Waris Islam.

JAS: Volume 1 Nomor 1, 2019 
Penelitian ini dilakukan dengan tujuan untuk mengetahui bagaimana kedudukan dan pengertian hak waris anak tiri dalam hukum waris Islam dan bagaimana cara mendapatkan bagian hak waris anak tiri dalam hukum waris Islam. Dengan demikian: 1. Anak tiri pada dasarnya adalah anak bawaan suami atau istri dari perkawinan sebelumnya. Yang secara hukum memiliki hubungan dengan perkawinan baru yang sah oleh ayah atau ibu-nya, dimana anak bawaan suami atau istri berstatus sebagai anak tiri dalam keluarga atau perkawinan yang baru ayah atau ibu-nya. Status sebagai anak tiri tidak menghilangkan hak waris anak tiri sebagai anak kandung dari ayah atau ibu kandung-nya yang membawa anak tiri kedalam perkawinan yang baru, serta kedudukan anak tiri dalam hak waris juga diakui secara hukum waris Islam sebagai Hijab Nuqshan (Penghalang yang berakibat berkurangnya bagian ahli waris). 2 . Anak tiri dalam hukum waris Islam tidak secara langsung tergolong sebagai ahli waris karena tidak terdapat sebab mewarisi (asbabul miirats). Tetapi dengan menggunakan alternatif lain dalam hukum waris Islam, anak tiri tidak akan kehilangan haknya untuk mendapatkan perlindungan dari orang tuanya, sebagai anak bawaan dari ayah dan ibu kandungnya. Dan dalam hukum waris Islam, anak tiri bisa mendapatkan harta warisan dari perkawinan ayah atau ibu kandung-nya yang baru (keluarganya yang baru) dengan cara Qiyas dan Wasiat Wajibah sebesar 1/3

\section{B. Metode}

Adapun metode kajian penelitian kualitatif ini sifatnya lebih ke arah metode kajian atas gagasan konseptual sedang data-data yang dikumpulkan dan yang akan dianalisis bertumpu pada ketersediaan sumber data di perpustakaan (Library Research) Sedang untuk teknik nalisis data yang digunkan dalam kajian ini adalah teknik Analisis isi (content analysis) yakni sebuah teknik yang secara komprehensip berusaha menggali beragam keterangan dari pesan atau informasi yang disajikan dalam wujud lambang atau simbol tertentu yang terdokumentasi atau dapat didokumentasikan. (Subrayogo, 2001:6) Sedang sumber data penelitian ini diperoleh dari beragam sumber yang bersifat kekinian dengan tidak meninggalkan referensi klasik 


\section{Hasil dan Pembahasan}

\section{a. Konsep Kewarisan Anak Tiri}

Di dalam agama islam, anak adalah hasil dari suatu perkawinan merupakan bagian yang penting kedudukannya dalam keluarga. Anak adalah amanah dari Allah SWT dan orangtua dari si anak wajib mengasuh, membesarkan dan mendidik anak tersebut. Disebutkan dalam pasal 45 dan 46 Undang-Undang Perkawinan Nomor 1 Tahun 1974, pernikahan membawa hukum antara orangtua dengan anak yang menimbulkan hak dan kewajiban diantara keduanya, dan disebutkan bawa sudah merupakan kewajiban bagi orang tua untuk mendidik dan mengasuh anaknya serta mengetahui cara mendidik anak menurut islam..

Demikian juga sang anak, ia wajib memenuhi hak dan kewajibannya sebagai anak dan mematuhi orangtuanya. Sehingga dari hal tersebut kita bisa menyimpulkan bahwa pernikahan tidak hanya menimbulkan kewajiban suami terhadap istri dan sebaliknya kewajiban isteri terhadap suami saja melainkan keduanya memiliki kewajiban terhadap anak.

Anak didalam suatu pernikahan dibagi menjadi beberapa golongan yakni anak kandung, anak tiri serta ada juga yang menyebutkan anak di luar kawin atau di luar nikah. Anak tiri adalah anak yang didapat dari pernikahan seseorang dengan pasangannya yang telah memiliki anak di masa lalu atau anak yang diperoleh dari pernikahannya terdahulu. Anak tiri ini bisa merupakan anak dari sang wanita ataupun anak dari sang pria. Biasanya pernikahan yang menimbulkan anak tiri adalah pernikahan dengan janda atau duda yang sudah memiliki anak. Anak tiri juga merupakan hasil dari perceraian orangtua terdahulunya karena ayahnya menjatuhkan talak pada ibunya atau salah satu dari keduanya meninggal.

Ketiga: al-Ijma' dan Ijtihad. Ijma' dan ijtihad para sahabat, imam-imam mazhab dan mujtahid-mujtahid kenamaan mempunyai peranan yang tidak kecil sumbangannya terhadap pemecahan-pemecahan masalah mawaris yang belum dijelaskan oleh nash-nash yang sharih.

\section{Syarat dan Rukun Kewarisan}

Untuk dapat menerima pusaka harus memenuhi beberapa rukun, beberapa sebab, beberapa syarat dan beberapa penghalang.

Menurut Teuku Muhammad Hasbi Ash-Shiddieqy (2001:32-34), untuk dapat menerima harta pusaka para ahli waris harus dapat memenuhi 2 syarat:

1. Ada harta yang di tinggalkan oleh pewaris

Agar hartanya dapat diwarisi oleh para ahli waris, disyaratkan ia benar-

JAS: Volume 1 Nomor 1, 2019 
benar telah meninggal, atau dipandang telah meninggal oleh keputusan hakim, kalau dia masih hidup maka dia sendiri yang berkuasa mengurus hartanya.

\section{Ada ahli waris}

Syarat untuk menjadi ahli waris adalah dia masih hidup pada waktu muwarisnya meninggal, baik meninggal secara hakikat ataupun menurut penetapan hakim, karena si waris mengganti muwarisnya adalah sesudah muwarisnya meninggal.

Sedang menurut menurut Drs. Fatchur Rahman (cet-10,79), syarat mempusakai adalah:

1. Matinya muwarits (orang yang mempusakakan)

2. Hidupnya warits (orang yang mempusakai) disaat kematian muwarits

3. Tidak ada penghalang mempusakai (mawani'ul irtsi)

Biarpun dua syarat pusaka-mempusakai itu telah ada pada muwarits dan warits, namun salah seorang dari mereka tidak dapat mempusakai harta peninggalannya kepada yang lain atau mempusakai yang lain jika masih ada penggalang mempusakai.

Rukun pusaka ada 3:

1. Muwarits, orang yang meninggalkan hartanya

2. Waris, orang yang ada hubungan dengan orang yang telah meninggal, seperti kekerabatan, hubungan darah dan perkawinan.

3. Mauruts, harta yang menjadi pusaka.

Istilah fiqh dinamakan: mauruts, mirats, irtsi, taurats, dan tarikah. (Ash Shiddiqiy, 2001:29)

Pada umumnya para ulama sepakat mengenai Syarat dan Rukun kewarisan.

\section{Sebab-sebab menerima warisan}

Hak-hak untuk mewarisi didasarkan atas berbagai hubungan antara si pewaris dengan si waris menurut perbedaan masa dan jalan pikiran serta tempat. Disini kita temukan tiga macam perbedaan ketiga-tiganya itu didaerah jazirah arab sekitar mekah dan madinah:

1. Sebab-sebab mewarsi dizaman Arab sebelum islam

a. Hubungan darah Mawaris disini berlaku hanya bagi laki-laki yang sanggup mengendarai JAS: Volume 1 Nomor 1, 2019 
kuda, memerangi musuh dan merebut rampasan perang dimusuh dan tidak berlaku lagi bagi wanita serta anak kecil biarpun laki-laki karena mereka tidak sanggup berperang.

b. Hubungan sebagai anak tiri

Seorang anak tiri, mendapat hak sebagai anak dalam hal mewaris dan lainnya.

c. Hubungan berdasarkan sumpah dan janji

Apabila dua orang bersumpah dan berjanji satu sama lain untuk menjadi saudara dan saling mewaris, jadilah mereka saling mewaris. Apabila salah seorang diantara mereka meninggal dunia, maka yang ditinggal hidup menjadi ahli waris atas harta peninggalan yang telah meninggal itu. (Thalib, 2002:69-70)

2. Sesudah datangnya Islam

Pada permulaan perkembangan islam tetap berlaku ketentuan-ketentuan menurut hukum adat arab yang telah berlaku sebelumnya. Kemudian sesudah hijrah kemedinah berangsur-angsur diterapkan ketentuan-ketentuan baru. Ketentuan-ketentuan berikut kemudian berangsur-angsur diterapkan sebagai dasar untuk mewarisi yaitu:

a. Hubungan Darah

Dalam hubungan darah ini tidak terbatas pada laki-laki yang sanggup berperang saja, tetapi berlaku bagi semua yang mempunyai hubungan darah.

b. Tidak diberlakukan lagi hubungan sebagai anak tiri untuk menjadi sebab mewaris.

Yang dimaksud disini berarti Allah memberi pernyataan bahwa kewarisan oleh seseorang sebagai anak tiri menurut hukum adat yang berlaku ketika itu tidaklah berlaku lagi.

c. Hubungan janji untuk mewaris.

Janji untuk mewaris tetap dipertahankan dalam permulaan islam. Kemudian mewaris berdasar atas perjanjian ini oleh sebagian sarjana islam, tidak diperlakukan lagi. Kata-kata "perjanjian" disini diartikan mereka sebagai hubungan perkawinan. Hubungan warisan berdasar janji ini diberi istilah oleh Hazairin dengan "Perjanjian Pertolongan".

d. Hijrah

JAS: Volume 1 Nomor 1, 2019 
Orang yang sesama hijrah dalam permulaan pengembangan islam itu saling mewaris sekalipun tidak mempunyai hubungan darah. Sedangkan dengan kaum kerabatnya yang tidak sesama hijrah dia tidak saling mewaris. Hubungan mewaris karena hijrah ini kemudian dihapus dan dimansukhkan dengan Q XXXIII:6 yang berbunyi:

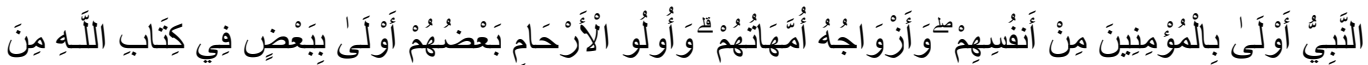

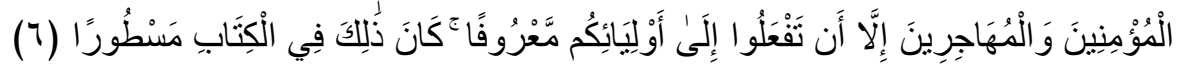

Artinya:"Nabi itu (hendaknya) lebih utama bagi orang-orang mukmin dari diri mereka sendiri dan isteri-isterinya adalah ibu-ibu mereka. dan orangorang yang mempunyai hubungan darah satu sama lain lebih berhak (waris-mewarisi) di dalam Kitab Allah daripada orang-orang mukmim dan orang-orang Muhajirin, kecuali kalau kamu berbuat baik kepada saudarasaudaramu (seagama). adalah yang demikian itu Telah tertulis di dalam Kitab (Allah). dan Q VIII:75 yang berbunyi:

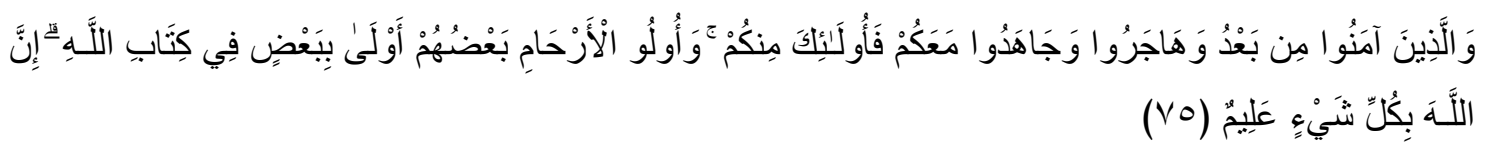

"Dan orang-orang yang beriman sesudah itu Kemudian berhijrah serta berjihad bersamamu Maka orang-orang itu termasuk golonganmu (juga). orang-orang yang mempunyai hubungan kerabat itu sebagiannya lebih berhak terhadap sesamanya (daripada yang bukan kerabat) di dalam Kitab Allah. Sesungguhnya Allah Maha mengetahui segala sesuatu."

"Orang yang sepertalian darah itu setengahnya lebih dekat kepada setengahnya".

e. Hubungan persaudaraan

Rasul mempersaudarakan orang-orang tertentu sesama karena keperluan yang ada pada suatu waktu. Dan tindakan Rasul itu, mulanya menjadi sebab mereka yang dipersaudarakan itu untuk saling mewarisi. Kedudukan waris karena dipersaudarakan itu saling mewaris. Setelah datangnya islam hal ini dimansukhkan dengan Q XXIII:6 dan Q VIII:75 dan sebagainya. (Thalib, JAS: Volume 1 Nomor 1, 2019 
2002:70-71)

Sesudah ayat-ayat kewarisan lengkap turunnya dan juga berdasar petunjuk-petunjuk dari Hadits Rasul yang berlaku menjadi penyebab pewarisan dalam islam adalah sebab-sebab:

a. Hubungan darah adalah ahli waris yang mendapatkan bagian yang telah ditetapkan secara jelas dan pasti di dalam Alquran serta telah ditetapkan bagiannya masing-masing. Besaran bagian masing-masing ahli waris adalah seperdua, seperempat, seperdelapan, sepertiga, dua pertiga dan seperenam. Ahli waris yang telah ditentukan bagiannya dalam Alquran, di antaranya, terdapat dalam QS. an-Nisa ayat 11. Ayat ini mengandung beberapa garis kewarisan Islam antara lain: Perolehan seorang anak lakilaki dan anak perempuan adalah dua berbanding satu (2:1); perolehan dua orang anak perempuan atau lebih adalah $2 / 3$; perolehan seorang anak perempuan adalah $1 / 2$; perolehan ibu dan bapak, masing-masing mendapat 1/6 dari harta warisan jika pewaris memiliki anak; perolehan ibu adalah $1 / 3$ jika pewaris tidak memiliki anak dan juga saudara; bagian ibu adalah 1/6 ketika pewaris tidak mempunyai anak, tetapi memiliki saudara; suami mendapat $1 / 2$ bagian dari harta peniggalan istrinya jika isterinya tidak mempunyai anak; suami memperoleh $1 / 4$ bagian dari harta warisan jika istri memiliki anak; istri mperoleh $1 / 4$ bagian dari harta peninggalan suami jika suami tidak memiliki anak, istri memperoleh $1 / 8$ bagian dari harta peninggalan suami jika ia memiliki anak; saudara perempuan atau saudara laki-laki masing-masing memperoleh 1/6 dari harta warisan jika pewaris tidak meninggalkan anak dan ayah; sauadara laki-laki atau perempuan yang berjumlah lebih dari dua orang, mereka secara bersama-sama mendapatkan 1/3 dari harta warisan jika pewaris tidak meninggalkan anak dan ayah.

b. Hubungan semenda/pernikahan adalah kelompok ahli waris yangmempunyai hubungan darah (kekerabatan) dengan pewaris, tetapi tidak mempunyai bagian yang telah ditentukan berdasarkan Alquran dan hadits serta tidak termasuk kelompok ahli waris asabah

c. Hubungan memerdekakan budak

Hubungan wasiat untuk tolan seperjanjian termasuk anak tiri. (Thalib, 2002:71)

d. Asabah adalah kelompok ahli waris yang tidak ditentukan bagiannya, kadangkala mendapat bagian sisa harta setelah diambil alih oleh ahli waris yang mempunyai bagian yang telah ditentukan dalam Alquran dan hadits. Kelompok ahli waris asabah terbagi atas 3 tingkatan, yakni: (a) asabah binafsi, (b) asabah bi ghairih, dan (c) asabah ma'a ghairih. Asabah binafsi 
adalah kelompok ahli waris yang berhak menerima seluruh harta warisan atau sisa harta dengan sendirinya tanpa dukungan ahli waris yang lain. Kelompok ini terdiri dari laki-laki dengan urutan sebagai berikut: Anak lakilaki, Cucu laki-laki (dari garis laki-laki), ayah, kakek, saudara kandung lakilaki, saudara laki-laki se-ayah, anak laki-laki dari saudara kandung, anak saudara laki-lai se-ayah, paman kandung, paman se-ayah, anak laki-laki paman kandung, dan anak laki-laki paman se-ayah. Asabah bi ghairih adalah ahli waris yang mulanya bukan ahli waris asabah karena dia perempuan, tetapi karena didampingi ahli waris laki-laki, maka dia menjadi asabah.

Adapun ahli waris yang termasuk kelompok ini adalah: Anak perempuan apabila bersama dengan anak laki-laki; Cucu perempuan bila bersama cucu laki-laki; Saudara perempuan sekandung bila bersama saudara laki-laki sekandung, dan Saudara perempuan se-ayah bila bersama saudara laki-laki se-ayah. Asabah ma'a ghairih adalah ahli waris yang semula tidak termasuk kelompok asabah, namun karena ahli waris tertentu bersamanya yang juga tidak termasuk kelompok asabah, sedangkan orang yang menyebabkannya menjadi asabah itu tetap bukan asabah. Adapun yang termasuk kelompok ini adalah saudara perempuan sekandung atau se-ayah apabila bersama dengan anak perempuan.

Dalam buku Fiqih Empat Madzab karya Muhammad Jawad Mughniyah, yang diterjemahkan oleh Masykur A.B, Afif Muhammad, dan Idrus Al-Kaff (2001:540), semua ulama sepakat dalam hal ini, bahwa sebab menerima warisan adalah

1. Hubungan kekerabatan

2. Hubungan perkawinan dengan akad yang sah

3. Hubungan wala'

\section{b. Keadilan Pembagian Harta Waris Menurut Hukum Islam}

Murtadha Muthahhari mengemukakan bahwa konsep adil dikenal dalam empat hal:

Pertama, adil bermakna keseimbangan dalam arti suatu masyarakat yang ingin tetap bertahan dan mapan, maka masyarakat tersebut harus berada dalam keadaan seimbang, di mana segala sesuatu yang ada di dalamnya harus eksis dengan kadar semestinya dan bukan dengan kadar yang sama. Keseimbangan sosial mengharuskan kita melihat neraca kebutuhan dengan pandangan yang relatif melalui penentuan keseimbangan yang relevan dengan menerapkan potensi yang semestinya terhadap

JAS: Volume 1 Nomor 1, 2019 
keseimbangan tersebut, sebagaimana yang terdapat di dalam QS. arRahman [55]: ayat 7: Dan Allah telah meninggikan langit dan Dia meletakkan neraca (keadilan). Para ahli tafsir menyebutkan bahwa yang dimaksud oleh ayat tersebut adalah keadaan alam yang diciptakan secara seimbang. Alam diciptakan dengan kadar yang semestinya dan jarak-jarak diukur dengan cara yang sangat cermat.

Kedua, adil adalah persamaan penafian terhadap perbedaan apa pun. Keadilan yang dimaksudkan adalah memelihara persamaan ketika hak memilikinya sama, sebab keadilan mewajibkan persamaan seperti itu, dan mengharuskannya.

Ketiga, adil adalah memelihara hak-hak individu dan memberikan hak kepada setiap orang yang berhak menerimanya. Hal ini sesuai dengan hadis yang diriwayatkan oleh Abu Umamah: Rasulullah saw bersabda: "Sesungguhnya Allah SWT telah memberi hak setiap orang yang berhak maka tidak ada wasiat bagi ahli waris". Keadilan seperti ini adalah keadilan sosial yang harus dihormati di dalam hukum. Keadilan seperti ini adalah keadilan sosial yang harus dihormati di dalam hukum manusia dan setiap individu diperintahkan untuk menegakkannya. Keempat, adil adalah memelihara hak atas berlanjutnya eksistensi.

\section{c. Penghalang Menerima Warisan}

Pada dasarnya yang termasuk terlarang untuk menerima warisan yang walaupun mereka termasuk ahli waris adalah berupa "status" dari seseorang, baik karena tindakan sesuatu ataupun karena keberadaannya dalam porsi tertentu sehingga berakibat jatuhnya hak mereka untuk mewarisi. Jadi "problem" disini adalah secara spesifik untuk para ahli waris yang dalam situasi tertentu tidak lagi berhak untuk memperoleh bagian asalnya. (Sarmadi, 1997:28-29). Para imam mazhab sepakat bahwa bahwa sebab-sebab yang menghalangi waris-mewaris ada tiga, yaitu:

1. Perbudakan

2. Pembunuhan

3. Berlainan agama. (Alkaf, 2001:324)

Akan tetapi ada juga yang menambahkan bahwa untuk menjadi penghalang menerima warisan adalah Berlainan negara. (Rahman, cet-10:83)

JAS: Volume 1 Nomor 1, 2019 


\section{d. Kewarisan Anak Tiri}

Anak tiri atau anak yang didapatkan dari pasangan dan dari pernikahan terdahulunya, tidaklah disebutkan menjadi bagian dari ahli waris berdasarkan $\mathrm{Al}$ qur'an dan Hadits. Hal ini terjadi dikarenakan anak tiri tidak memiliki hubungan atau sebab yang membuatnya dapat mewarisi harta orangtua tirinya. Sebab mendapatkan warisan atau yang disebut dengan asbabul mirats hanya terdiri dari tiga hal saja, yaitu

1. Hubungan kekerabatan atau qarabah, hal ini menyangkut anak kandung atau orang yang terkait nasab dengan sang pemilik harta atau disebut juga sebagai sebab garis keturunan atau yang lebih dikenal dengan garis nasab

2. Hubungan perkawinan (mushaharah), yaitu adanya hubunganantara orang yang mewarisi tersebut dengan seseorang akibat adanya hubungan pernikahan. Dalam hal ini haruslah nikah secara resmi bukanlah nikah siri, pernikahan sedarah, atau pernikahan lainnya yang hukumnya tidak sah secara agama. Jika telah bercerai maka bekas pasangannya tersebut tidaklah berhak mendapatkan harta warisan.

3. Dikarenakan memerdekakan budak atau yang disebut dengan hak wala. Orang yang memerdekakan budak lalu suatu hari budaknya tersebut memiliki harta dan meninggal maka orang yang memerdekakan tersebut berhak mendapatkan harta warisan dari budak yang telah dimerdekakannya tersebut.

Dengan melihat ketiga sebab waris diatas maka kita dapat menyimpulkan bahwa anak tiri tidak berhak atau tidak dapat mewarisi harta orangtua tirinya tersebut, ia hanya bisa mendapatkan waris dari orangtua yang sedarah dengannya baik ibu maupun ayah, Adapun anak tiri tidak berhak mendapatkan harta warisan adalah berdasarkan dalil dalam Alqur'an yang menjadi dasar hukum waris berikut ini:

\section{- An Nisa ayat 7}

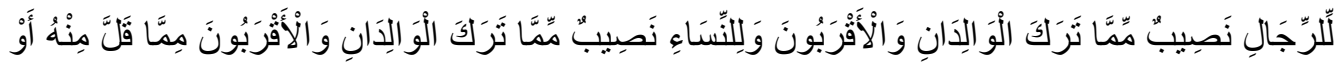

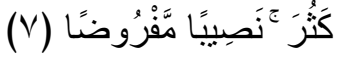

Yang artinya:"Bagi laki-laki ada hak bagian dari harta peninggalan ibu bapak dan kerabatnya, dan bagi wanita ada hak bagian (pula) dari harta peninggalan ibu bapak dan kerabatnya, baik sedikit atau banyak menurut bahagian yang telah ditetapkan"

JAS: Volume 1 Nomor 1, 2019 
- Surat An-Nisa' ayat 11

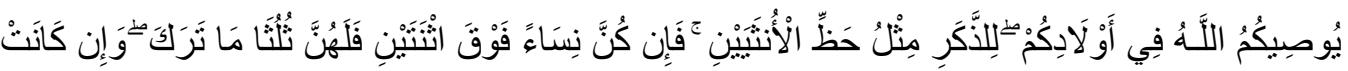

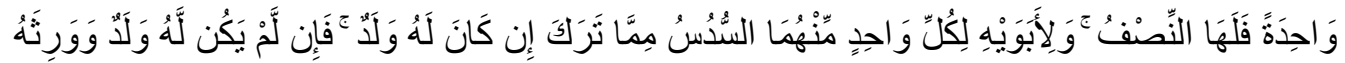

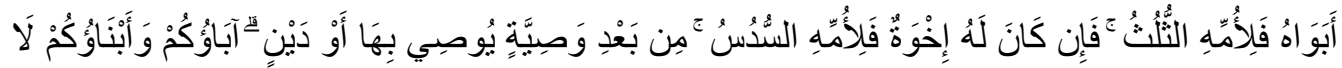

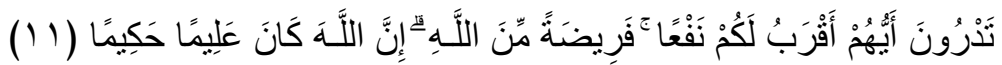

"Allah mensyariatkan (mewajibkan) kepadamu tentang (pembagian warisan untuk) anak-anakmu, (yaitu) bagian seorang anak laki-laki sama dengan bagian dua orang anak perempuan. Dan jika anak itu semuanya perempuan yang jumlahnya lebih dari dua, maka bagian mereka dua pertiga dari harta yang ditinggalkan. Jika dia (anak perempuan) itu seorang saja, maka dia memperoleh setengah (harta yang ditinggalkan). Dan untuk kedua ibu bapak, bagian masing-masing seperenam dari harta yang ditinggalkan, jika dia (yang meninggal) mempunyai anak. Jika dia (yang meninggal) tidak mempunyai anak dan dia diwarisi oleh kedua ibu-bapaknya (saja), maka ibunya mendapat sepertiga. Jika dia (yang meninggal) mempunyai beberapa saudara, maka ibunya mendapat seperenam. (Pembagian-pembagian tersebut di atas) setelah (dipenuhi) wasiat yang dibuatnya atau (dan setelah dibayar) hutangnya. (Tentang) orangtuamu dan anak-anakmu, kamu tidak mengetahui siapa di antara mereka yang lebih banyak manfaatnya bagimu. Ini adalah ketetpan Allah. Sungguh, Allah Maha Mengetahui, Mahabijaksana."

\section{- Surat An-Nisa' ayat 12}

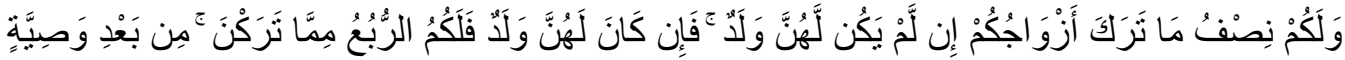

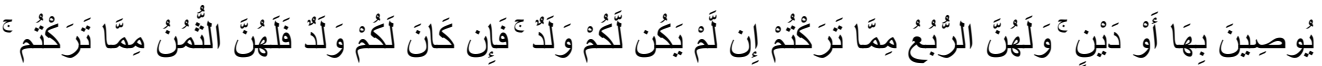

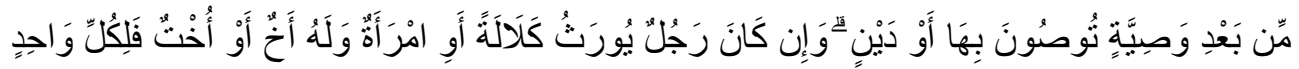

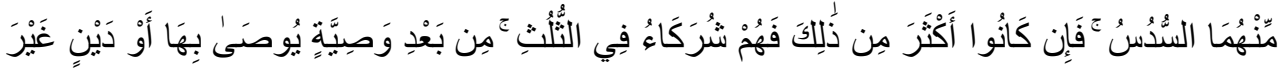

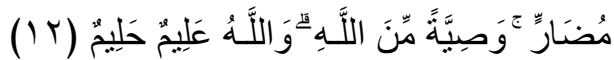

"Dan bagimu (suami-suami) seperdua dari harta yang ditinggalkan oleh isteri-isterimu, jika mereka tidak mempunyai anak. Jika isteri-isterimu itu mempunyai anak, maka kamu mendapat seperempat dari harta yang ditinggalkannya sesudah dipenuhi wasiat yang mereka buat atau (dan) sesudah dibayar hutangnya. Para isteri memperoleh seperempat harta yang kamu tinggalkan jika kamu tidak mempunyai anak. Jika kamu mempunyai 
anak, maka para isteri memperoleh seperdelapan dari harta yang kamu tinggalkan sesudah dipenuhi wasiat yang kamu buat atau (dan) sesudahnya.

Demikian penjelasan dan dalil hukum Waris yang terkait dengan hak waris anak tiri atas harta orangtua tirinya. Dari pernyataan dan uraian diatas maka jelaslah bahwa anak tiri tidaklah memiliki hak waris atas harta orangtua tirinya dan ia hanya berhak terhapa hak waris orangtua kandungnya saja sebagaimana tercantum dalam ayat-ayat di atas. Hal ini perlu diketahui agar tidak terjadi konflik dalam keluarga yang disebabkan oleh harta warisan

Apabila seorang laki-laki menikah dengan seorang janda yang telah mempunyai anak kemudian dari pernikahan tersebut dikaruniai anak maka pada saat laki-laki tersebut meninggal bagaimana pembagian harta warisnya menurut islam? Apakah anak bawaan istri tersebut mendapat warisan juga?

Sebagaimana terdapat dalam Pasal 171 huruf c Kompilasi Hukum Islam ("KHI"), ahli waris adalah orang yang pada saat meninggal dunia mempunyai hubungan darah atau hubungan perkawinan dengan pewaris, beragama Islam dan tidak terhalang karena hukum untuk menjadi ahli waris.

Kompilasi Hukum Islam yang dikemas dalam bentuk Instruksi Presiden tidak termasuk peraturan perundang-undangan sebagaimana dimaksud oleh Ketetapan MPRS Nomor XX/MPRS/1968 juncto Ketetapan MPR Nomor V/MPR/1973 juncto Ketetapan MPR Nomor IX/MPR/1978. Oleh karena itu, Kompilasi Hukum Islam juga tidak memiliki salah satu ciri peraturan perundang-undangan, yaitu tentang paksaan berlakunya.

Dari apa yang terurai diatas dapat disimpulkan bahwa anak tiri menurut pasal 171 huruf h Kompilasi Hukum Islam dapat disimpulkan:

a. Status Anak tiri hanya terbatas pada peralihan pemeliharaan hidup sehari-hari dan tanggung jawab biaya pendidikan

b. Kaabsahan statusnya harus berdasar putusan keputusan Pengadilan

c. Dalam pasal 209 memberikan wasiat wajibah sepertiga kepada anak tiri. (Basri, 1999:67)

Kewarisan anak tiri berdasar pasal 209 Kompilasi Hukum Islam di Indonesia yang berbunyi: "Terhadap Anak Tiri yang tidak menerima wasiat diberi wasiat wajibah sebanyak-banyaknya sepertiga dari harta warisan orang tua tirinya". (Bisri, 1999:206)

JAS: Volume 1 Nomor 1, 2019 
Pasal ini dapat ditafsirkan sebagai berikut:

1. Seorang anak tiri tetap mempunyai hubungan kewarisan dengan orang tua kandungnya maupun kerabat-kerabatnya.

2. Anak tiri hanya mungkin memperoleh harta peninggalan dari orang tua tirinya dengan jalan wasiat atau wasiat wajibah. Besarnya wasiat wajibah tidak lebih dari sepertiga dari keseluruhan harta orang tua tirinya. (Budiono, 199:194)

Pada dasarnya seseorang itu bebas apakah membuat atau tidak membuat wasiat. Akan tetapi sebagian ulama berpendapat bahwa kebebasan untuk membuat wasiat atau tidak itu hanya berlaku untuk orang yang bukan kerabat dekat. Mereka berpendapat bahwa untuk kerabat dekat yang tidak mendapatkan warisan, seseorang wajib membuat wasiat. Hal ini didasarkan pada Al-Qur'an surat alBaqarah ayat 180, Hal ini pendapat dari Ahmad bin Hambal, Ibnu Hazin, Said Ibnul Musayyab, Al-Hasanul Bishri, dll. (Budiono, 1999:25).

Yang dimaksud dengan wasiat wajibah menurut Direktorat RI, Jendral kelembagaan agama Islam (2002:120) mendefinisikan adalah wasiat yang pelaksanaannya tidak dipengaruhi atau tidak bergantung pada kemauan atau kehendak yang meninggal dunia. Wasiat ini harus tetap dilaksanakan baik diucapkan maupun tidak diucapkan, baik dikehendaki maupun tidak dikehendaki oleh yang meninggal dunia. Jadi pelaksanaan wasiat tersebut tidak memerlukan bukti bahwa wasiat tersebut diucapkan atau ditulis atau dikehendaki, tetapi pelaksanaannya didasarkan kepada alasan-alasan hukum yang membenarkan bahwa wasiat tersebut harus dilaksanakan.

KUH Wasiat Mesir tentang wasiat wajibah No. 71 Th 1365 H dan Th 1946 M dapat disimpulkan:

a) Wasiat wajibah berlaku dengan sendirinya walaupun tidak diwasiatkan sebelumnya oleh pewasiat (pewaris)

b) Wasiat wajibah yang dimaksud adalah kepada orang yang bukan ahli waris tetapi kepada mereka yang karena tidak tergolong ahli waris seperti cucu lakilaki atau perempuan pancar perempuan (anak-anak dari anak perempuan) yang meninggal atau kepada cucu laki-laki atau perempuan pancar Laki-laki (anak-anak dari anak laki-laki pewaris yang meninggal), mereka terhijab karena adanya anak laki-laki pewaris langsung. Maka untuk mereka berhak menerima wasiat wajibah tanpa harus adanya persetujuan ahli waris maupun pewaris saudara sebelumnya ketika ia masih hidup.

c) Batas maksimal wasiat wajibah adalah sepertiga dari harta peninggalan, apabila pewaris sebelumnya telah mewasiatkan kepada mereka harta yang kurang

JAS: Volume 1 Nomor 1, 2019 
sepertiga bagian, maka secara yuridis harus di cukupkan sepertiga harta dan apabila wasiat tersebut melebihi dari batas maksimal sepertiga harta, selebihnya merupakan wasiat ikhtiarah, dimana adanya keharusan persetujuan ahli waris, apakah ahli waris menyetujuinya berarti mereka akan mendapatkan kelebihan dari sepertiga harta dan sebaliknya jika kelebihan tersebut tidak disetujui ahli waris maka kelebihan tersebut diambil untuk dijadikan tambahan dari harta pewarisan bagi ahli waris. (Sarmadi, 1997:260-261).

Dari paparan dapat diambil kesimpulan bahwa seorang anak tiri dengan orang tua tiri tidak ada hubungan kewarisan, akan tetapi sebagai pengukuhan dari Lembaga pengangkatan anak, pada prakteknya Kompilasi Hukum Islam mewajibkan agar orang tua tiri memberi wasiat wajibah walaupun orang tua tiri tidak mewasiatkan kepada anak tiri tersebut.

Terdapat 25 ahli waris yang diatur didalam hukum waris Islam, yang dapat mewarisi harta pewaris yang terdiri dari 15 orang laki-laki dan 10 orang perempuan. Anak tiri tidak secara langsung termasuk golongan ahli waris menurut hukum Islam. Tetapi bukan berarti anak tiri tidak bisa mendapatkan warisan. Anak tiri tidak secara langsung terhubung dengan ayah atau ibu tirinya.

Namun anak tiri (anak bawaan dari ibu atau ayah kandung-nya dari perkawinan sebelumnya) dalam status perkawinan yang baru atau keluarga yang baru berhak mendapatkan warisan sebagai anak kandung dari ibu atau ayah kandung-nya. Anak tiri atau anak bawaan tidak secara langsung terhubung dengan orang tua tiri-nya. Namun saat telah terjadi perkawinan yang sah, maka secara hukum anak tiri atau anak bawaan telah memiliki hubungan hukum dengan keluarga baru-nya.

Adanya hubungan hukum menimbulkan akibat hukum atas keberadaan anak tiri bagi ibu dan ayah tiri dalam menerima warisan. Muhammad 'Ali Ash Shabuniy bahwa, walaupun beliau berpendapat dalam kasus Gharaqiy, bahwa anak tiri tidak mendapat bagian apa-apa dari harta warisan Ibu atau Bapak tiri-nya, namun pada bagian lain beliaumengemukakan bahwa anak tiri juga bisa menjadi Hijab Nuqshan (Penghalang yang berakibat berkurangnya bagian ahli waris) terhadap ibu atau ayah tiri-nya, sebagaimana Firman Allah SWT. Dalam QS. An-Nisaa' ayat 12, dengan penjelasan bahwa suami mendapat bagian $1 / 4$ apabila istri mempunyai anak atau anak dari anak laki-laki (cucu) dan seterusnya ke bawah, baik anak itu dari suami tersebut, maupun dari lainnya (suami terdahulu). Istri mendapat bagian $1 / 4$ apabila suami tidak mempunyai anak atau anak dari anak laki-laki (cucu) dan seterusnya ke 
bawah, baik anak itu dari istri tersebut maupun dari istri yang lainnya.13 Anak tiri pada dasarnya adalah anak bawaan suami atau istri dari perkawinan sebelumnya.

\section{Simpulan}

Konsep keadilan dalam hukum waris Islam adalah pemberian hak-hak dan kewajiaban kepada setiap orang yang berhak menerimanya. Sebagaimana hikmah pemberian warisan laki-laki yang besarannya adalah dua kali lipat dari harta warisan yang diterima perempuan dikarenakan laki-laki selain membiayai kehidupannya sendiri juga berkewajiban menafkahi keluarganya. Selain itu, keadilan dalam waris Islam juga berlandaskan pada asas keadilan berimbang, sehingga dalam beberapa kasus pembagian harta waris tertentu, bagian perempuan dapat menyamai bagian laki-laki atau melebihinya. Oleh karena itu, terbentuklah sistem kewarisan yang memprioritaskan persamaan hak-hak setiap ahli waris dalam pemabagian harta warisan, seperti pemberian bagian warisan yang sama rata antara ahli waris laki-laki dan perempuan. Tetapi terdapat kasus khusus pada anak angkat dan anak tiri.

Anak tiri pada dasarnya adalah anak bawaan suami atau istri dari perkawinan sebelumnya. Yang secara hukum memiliki hubungan dengan perkawinan baru yang sah oleh ayah atau ibu-nya, dimana anak bawaan suami atau istri berstatus sebagai anak tiri dalam keluarga atau perkawinan yang baru ayah atau ibu-nya. Status sebagai anak tiri tidak menghilangkan hak waris anak tiri sebagai anak kandung dari ayah atau ibu kandung-nya yang membawa anak tiri kedalam perkawinan yang baru, serta kedudukan anak tiri dalam hak waris juga diakui secara hukum waris Islam sebagai Hijab Nuqshan (Penghalang yang berakibat berkurangnya bagian ahli waris).

Anak tiri dalam hukum waris Islam tidak secara langsung tergolong sebagai ahli waris karena tidak terdapat sebab mewarisi (asbabul miirats). Tetapi dengan menggunakan alternatif lain dalam hukum waris Islam, anak tiri tidak akan kehilangan haknya untuk mendapatkan perlindungan dari orang tuanya, sebagai anak bawaan dari ayah dan ibu kandung-nya. Dan dalam hukum waris Islam, anak tiri bisa mendapatkan harta warisan dari perkawinan ayah atau ibu kandung-nya yang baru (keluarganya yang baru) dengan cara Qiyas dan Wasiat Wajibah sebesar $1 / 3$.

JAS: Volume 1 Nomor 1, 2019 
Jadi pada dasarnya yang dapat menjadi ahli waris menurut hukum Islam adalah orang yang mempunyai hubungan darah dengan pewaris, atau memiliki hubungan perkawinan dengan pewaris (suami atau istri pewaris). Ahli waris terbatas pada 3 (tiga) sebab saja, yaitu:

1. Sebab kekerabatan (qarabah), atau disebut juga sebab nasab (garis keturunan).

2. Sebab perkawinan (mushaharah), yaitu antara mayit dengan ahli waris ada hubungan perkawinan. Maksudnya adalah, perkawinan yang sah menurut Islam, bukan perkawinan yang tidak sah, dan perkawinan yang masih utuh (tidak bercerai).

3. Sebab memerdekakan budak (wala').

Tetapi kepada anak tiri mubah (boleh) hukumnya untuk diberi wasiat oleh orang tua tirinya. Dengan syarat, harta yang diberikan sebagai wasiat itu tidak melebihi $1 / 3$ (sepertiga) dari harta orang tua tirinya yang meninggal. Jika wasiatnya melebihi $1 / 3$ (sepertiga), maka pelaksanaanya bergantung pada persetujuan para ahli waris.

\section{DAFTAR PUSTAKA}

Al-Qur'an al-Karim

Al-Hadits

Abdurrahman, 1992. Kompilasi Hukum Islam di Indonesia, Jakarta: Akademia Pressindo.

Ad-Dimisyqi, Syaikh al-Alamah Muhammad bin Abdurrahaman, Fiqih Empat Mazhab, Terjemahan: Abdullah Zaki Alkaf, 2001. Jakarta: Hasyimi Press.

AGA, Nurhadi, 2002. Sejarah Fiqih Islam, Jakarta: Pustaka al-Kautsar.

Ash Shiddieqy, Teungku Muhammad Hasbi, 2001. Fiqih Mawaris, Semarang: Pustaka Rizki Putra.

Budiono, Rachmad, 1999. Pembaruan Hukum Kewarisan Islam di Indonesia, Bandung: Citra Aditya Bakti.

Mahjuddin, 2003. Masail Fiqhiyah, Jakarta: Kalam Mulia.

Mansoer, 1976. Imam Syafi'i dan Nilai Musnadnya, Bandung: AlMa'arif.

JAS: Volume 1 Nomor 1, 2019 
Mubarok, Jaih, 2002. Modifikasi Hukum Islam Studi Qoul Qodim dan Qoul Jadid, Jakarta: Raja Grafindo Persada.

Mughniyah, Muhammad Jawad, Fiqih Lima Madzab, Terjemahan: Masykur AB, Afif Muhammad, Idrus Al-Kaff, 2001. Jakarta: Lentera Basritama.

Rahman, Fatchur, cet-10. Ilmu Waris, Bandung: Alma'arif.

Ramulyo, M. Idris, 1984. Hukum Kewarisan Islam: Studi kasus, Perbandinagan ajaran Syafi'i (Patrilineal), Hazairin (Bilateral), dan Praktek di Pengadilan Agama, Jakarta: Ind-HILL.Co.

RI, Departemen Agama, 2002. Islam untuk Disiplin Ilmu Hukum, Jakarta: Direktorat Jenderal Kelembagaan Agama Islam.

Rofiq, Ahmad, 2001. Pembaharuan Hukum Islam di Indonesia, Yogyakarta: Gama Media.

Sarmadi, A. Sukris, 1997. Transedensi Hukum Waris Islam Transformatif, Jakarta: Raja Grafindo Persada.

Soeroso, R, 1995. Perbandingan Hukum Perdata, Jakarta: Sinar Grafika.

Syakah, Asy, 1995. Islam Tidak Bermazhab, Jakarta: Gema Insani Press.

Thalib, Sajuti, 2002. Hukum Kewarisan Islam di Indonesia, Jakarta; Sinar Grafika.

Wahid, Marzuki, dan Rumadi, 2001. Fiqh Madzhab Negara: Kritik Atas Politik Hukum Islam di Indonesia, Yogyakarta:LKiS.

JAS: Volume 1 Nomor 1, 2019 